Jurnal InFestasi

Vol. 11, No.2, Desember 2015

Hal. 118 - 136

\title{
PENGARUH KINERJA KEUANGAN TERHADAP PERTUMBUHAN EKONOMI DAERAH DENGAN ALOKASI BELANJA MODAL SEBAGAI VARIABEL INTERVENING (Studi pada Pemerintah Kabupaten/Kota D.I. Yogyakarta)
}

\author{
Kurni Adi Suwandi \\ Afrizal Tahar \\ Universitas Muhammadiyah Yogyakarta
}

\begin{abstract}
This study aims to to test empirically the influence of the financial performance of the local government which measured by the ratio of fiscal decentralization degrees, fiscal dependence, financial independence, the effectiveness of local revenue (PAD), and the degree of the contribution of BUMD to the ratio allocation capital expenditure. The population of this research is all local governments districts/city in D.I.Yogyakarta year 2003-2012. The result of this research shows thatthe ratio of degrees fiscal decentralization and fiscal dependence have a negative influence on the allocation of capital expenditure, the ratio of the effectiveness of local revenue (PAD) have a positive influence on the allocation of capital expenditure, and the ratio of the contribution of $B U M D$ degrees does not affect the allocation of capital expenditure. The allocation of capital expenditure have a positive influence on the growth of regional economic. The allocation of capital expenditure cannot mediate the affect between the ratio of fiscal decentralization degrees, the effectiveness of local revenue (PAD), and the degree of the contribution of bumd on the growth of regional economic. But the allocation of capital expenditure can mediate the affect between fiscal dependence on the growth of regional economic.
\end{abstract}

Keywords :Degrees Fiscal Decentralization, Fiscal Dependence, Financial Independence, The Effectiveness of Local Revenue, The Contribution of BUMD Degrees, The Allocation of Capital Expenditure, and Regional Economic Growth.

\begin{abstract}
Abstrak
Penelitian ini bertujuan untuk menguji secara empiris pengaruh kinerja keuangan pemerintah daerah yang diukur dengan rasio derajat desentralisasi fiskal, ketergantungan fiskal, kemandirian finansial, efektivitas pendapatan asli daerah (PAD), dan tingkat kontribusi BUMD terhadap belanja modal alokasi rasio. Populasi penelitian ini adalah seluruh pemerintah daerah kabupaten / kota di D.I. Yogyakarta tahun 2003-2012. Hasil penelitian ini menunjukkan bahwa rasio derajat desentralisasi fiskal dan ketergantungan fiskal memiliki pengaruh negatif pada alokasi belanja modal, rasio efektivitas pendapatan asli daerah (PAD) memiliki pengaruh positif pada alokasi belanja modal, dan rasio kontribusi BUMD derajat tidak mempengaruhi alokasi belanja modal. Alokasi belanja belanja modal memiliki pengaruh positif terhadap pertumbuhan ekonomi daerah. Belanja modal daerah tidak memiliki efek memediasi atas hubungan rasio derajat desentralisasi fiskal, efektivitas pendapatan asli daerah (PAD), dan tingkat kontribusi BUMD terhadap pertumbuhan ekonomi daerah. Namun alokasi belanja modal dapat memediasi hubungan antara ketergantungan fiskal terhadap pertumbuhan ekonomi regional.
\end{abstract}

Kata kunci: Derajat Desentralisasi Fiskal, Ketergantungan Fiskal, Keuangan Kemerdekaan, Efektifitas Pendapatan Daerah, Kontribusi BUMD Degrees, Alokasi Belanja Modal, dan Pertumbuhan Ekonomi Daerah. 


\section{PENDAHULUAN}

Krisis ekonomi yang terjadi pada awal tahun 1996 dan puncaknya pada tahun 1997 mendorong pemerintah pusat mendelegasikan sebagian wewenang untuk pengelolaan keuangan kepada daerah sehingga diharapkan daerah dapat membiayai pembangunan dan pelayanan atas dasar keuangan sendiri (Azhar, 2008). Otonomi daerah merupakan kebijakan yang diambil oleh pemerintah pusat agar pemerintah daerah dapat mengelola pemerintahannya sendiri tanpa campur tangan dari pemerintah pusat (Fitriyanti dan Pratolo, 2009). Otonomi daerah diberlakukan dengan diterbitkannya UU No. 22 dan 25 tahun 1999 kemudian direvisi melalui UU No. 32 tahun 2004 tentang Pemerintahan Daerah. Dengan demikian, pemerintah daerah diharapkan dapat mengelola sumber daya yang dimilikinya dan melaksanakan tata kelola pemerintahan yang baik sehingga akan berdampak pada pelayanan yang diberikan kepada masyarakat (Handra dan Maryati, 2009). Pemerintah daerah mempunyai hak dan wewenang yang luas untuk menggunakan sumber-sumber keuangan yang dimilikinya sesuai dengan kebutuhan dan aspirasi masyarakat yang berkembang di daerah. Hal ini juga menegaskan bahwa daerah memiliki kewenangan untuk menentukan alokasi sumber daya ke dalam belanja dengan menganut asas kepatutan, kebutuhan, dan kemampuan daerah (Nugroho, 2010).

Pengelolaan keuangan daerah yang baik akan berpengaruh terhadap kemajuan suatu daerah. Pengelolaan keuangan daerah yang dilakukan secara ekonomis, efisien, dan efektif atau memenuhi prinsip value for money serta partisipasi, transparansi, akuntabilitas dan keadilan akan dapat mendorong pertumbuhan ekonomi. Pengelolaan keuangan daerah yang baik tidak hanya membutuhkan sumber daya manusia yang handal tetapi juga harus didukung oleh kemampuan keuangan daerah yang memadai. Tingkat kemampuan suatu daerah dapat diukur dengan besarnya penerimaan daerah. Upaya pemerintah daerah dalam menggali kemampuan daerah dapat diukur menggunakan analisis rasio keuangan pemerintah daerah. Pengukuran kinerja pemerintah daerah dapat dijadikan sebagai penilaian akuntabilitas dan kemampuan suatu daerah penyelenggara otonomi daerah. Dengan demikian maka suatu daerah yang kinerja keuangannya dinyatakan baik berarti daerah tersebut memiliki kemampuan keuangan untuk membiayai pelaksanaan otonomi daerah (Sularso dan Restianto, 2011).

Pengelolaan keuangan yang harus dilakukan sendiri oleh pemerintah daerah menuntut adanya kemandirian daerah dalam menggali menggali potensi lokal dan meningkatkan kinerja keuangannya. Kemandirian daerah ini dicerminkan dengan kemampuan daerah menghasilkan penerimaan pendapatan yang diperoleh daerah yang berasal dari potensi-potensi ekonomi daerah atau yang disebut juga pendapatan asli daerah (Rusydi, 2010). PAD dapat dialokasikan untuk kegiatan publik yang merupakan salah satu harapan masyarakat kepada pemerintah di era desentralisasi fiskal ini (Kawa, 2011). Namun, kenyataannya tidak semua daerah mampu untuk lepas dari pemerintah pusat, dikarenakan tingkat kebutuhan tiap daerah berbeda. Maka pemerintah pusat tidak dapat begitu saja lepas tangan terhadap kebijakan otonominya. Oleh karena itu, pemerintah pusat pada akhirnya akan melakukan transfer dana, yang berupa dana perimbangan yang ditujukan untuk keperluan pemerintah daerah. untuk sebagian daerah alokasi dana transfer ini justru menjadi sumber pendapatan daerahnya, sehingga kemandirian daerah sebenarnya belum sepenuhnya terlaksana (Christy dan Adi, 2009).

Akan tetapi otonomi daerah yang saat ini sudah berjalan di tiap Kabupaten dan Kota D.I. Yogjakarta tetap menimbulkan persoalan baru, karena ternyata potensi fiskal pemerintah daerah yang satu dengan daerah yang lainnya masih beragam. Hal ini disebabkan oleh kesiapan fiskal dari masing-masing daerah yang berbeda dalam pelaksanaan otonomi daerah (Nordiawan, Iswahyudi, dan Maulidah, 2007 dalam Kawa, 2011). Perbedaan yang terjadi ini akan menghasilkan pertumbuhan ekonomi yang beragam 
pula. Hal ini disebabkan karena dengan adanya peningkatan Pendapatan Asli Daerah (PAD), maka dana yang dimiliki oleh pemerintah daerah tersebut akan lebih tinggi, sehingga pemerintah daerah akan berinisiatif untuk menggali potensipotensi daerah dan akhirnya akan meningkatkan pertumbuhan ekonomi (Harianto dan Adi, 2007).

Pemberian otonomi daerah memang berpengaruh terhadap pertumbuhan ekonomi suatu daerah karena memberikan kebebasan kepada pemerintah daerah untuk membuat rencana keuangannya sendiri dan membuat kebijakan-kebijakan yang dapat berpengaruh pada kemajuan daerahnya. Pertumbuhan ekonomi mendorong pmerintah daerah untuk melakukan pembangunan ekonomi dengan mengelola sumber daya yang ada dan membentuk lapangan kerja baru yang akan mempengaruhi perkembangan kegiatan ekonomi daerah tersebut (Utomo, 2012). Namun, kenyataan yang terjadi dalam pemerintahan saat ini adalah dengan adanya peningkatan pertumbuhan ekonomi daerah ternyata tidak selalu diikuti dengan peningkatan alokasi belanja modal yang dianggarkan lebih kecil dari belanja pegawai dari total anggaran belanja tiap tahunnya (Utomo, 2012). Padahal belanja modal merupakan stimulus bagi pertumbuhan ekonomi daerah. Konsekuensinya, pemerintah perlu memberikan alokasi belanja modal yang lebih besar (Nugroho, 2010). Adapun yang menyatakan, bahwa pemerintah memang perlu untuk meningkatkan investasi modal guna meningkatkan pertumbuhan ekonomi daerah (Lin dan Liu, 2000 dalam Kawa, 2011).

Adi (2007), menyatakan bahwa pertumbuhan ekonomi yang selama ini terjadi sangat ditentukan oleh faktor belanja pembangunan daerah. Hal ini sejalan dengan pendapat Kuncoro (2004) yang mengemukakan bahwa pembangunan sarana dan prasarana oleh pemerintah daerah berpengaruh positif pada pertumbuhan ekonomi.Hamzah (2008), menyatakan bahwa pertumbuhan ekonomi suatu daerah dipengaruhi oleh kinerja keuangan pemerintah daerah, ditunjukkan dengan rasio kemandirian dan rasio keserasian berpengaruh positif secara signifikan terhadap pertumbuhan ekonomi, sedangkan rasio efektivitas tidak berpengaruh secara signifikan terhadap pertumbuhan ekonomi. Harianto dan Adi (2007), mengatakan bahwa pendapatan asli daerah berpengaruh terhadap pertumbuhan ekonomi. Kawa (2011), menyatakan bahwa rasio kemandirian daerah, rasio efektifitas PAD, dan rasio efisiensi anggaran tidak berpengaruh signifikan terhadap pertumbuhan ekonomi, rasio keserasian belanja operasional dan rasio keserasian belanja modal berpengaruh positif secara signifikan terhadap pertumbuhan ekonomi.

Berdasarkan paparan di atas, maka penelitian ini bertujuan untuk menguji pengaruh kinerja keuangan (rasio derajat desentralisasi, ketergantungan keuangan, kemandirian keuangan, efektivitas PAD, dan derajat kontribusi BUMD) terhadap alokasi belanja modal. Selain itu, penelitian ini juga akan menguji pengaruh alokasi belanja modal terhadap pertumbuhan ekonomi daerah, serta pengaruh mediasi alokasi belanja modal antara kinerja keuangan terhadap pertumbuhan ekonomi daerah.

\section{Desentralisasi dan Federalisme Fiskal}

Secara umum, desentralisasi dapat diartikan sebagai pelimpahan wewenang dari pemerintah pusat ke level pemerintahan yang ada di bawahnya. Secara teoritis ada beberapa tipe desentralisasi, yaitu desentralisasi politik, desentralisasi administratif, dan desentralisasi fiskal (Osoro, 2003 dalam Khusaini, 2006). Menurut Undang-Undang Nomor 32 Tahun 2004 Pasal 7 Desentralisasi adalah penyerahan wewenang pemerintah oleh pemerintah pusat kepada daerah otonom dalam kerangka Negara Kesatuan Republik Indonesia. Desentralisasi fiskal dapat dimaknai sebagai pelimpahan kewenangan di bidang penerimaan anggaran atau keuangan yang sebelumnya tersentralisasi, baik secara administrasi maupun pemanfaatannya diatur atau dilakukan oleh pemerintah pusat (Khusaini, 2006). Pengertian di atas mengisyaratkan bahwa desentralisasi memberikan ruang gerak yang lebih bagi pemerintah daerah 
untuk berimprovisasi dalam hal pemanfaatan sumber daya dan potensi daerah serta kebijakan-kebijakan yang berorientasi pada kebutuhan daerah, seperti pelaksanaan tugas-tugas rutin, pelayanan publik, dan peningkatan investasi yang produktif (capital investment) di daerahnya. Secara teori, desentralisasi akan mendekatkan pemerintah kepada masyarakat sehingga dalam sistem pemerintahan yang desentralistik akan tercipta efisiensi dalam perekonomian, sehingga pada gilirannya akan meningkatkan kesejahteraan masyarakat.

Berdasarkan Undang-Undang Nomor 32 Tahun 2004 dan UndangUndang Nomor 33 Tahun 2004, tujuan dari desentralisasi fiskal di Indonesia adalah : (1) Kesinambungan fiskal (fiscal sustainability) dalam konteks ekonomi makro, (2) Mengoreksi vertical imbalance, yaitu mereduksi ketimpangan antara keuangan pemerintah pusat dengan pemerintah daerah. Hal ini dilakukan dengan memperbesar taxing power daerah, (3) Mengoreksi horizontal imbalance, yaitu memperkecil disparitas antar daerah dengan mekanisme block grant/transfer dan memperbesar kewenangan daerah untuk menerapkan kebijakan pembangunan yang sesuai dengan kebutuhan, potensi, dan sumber daya yang dimiliki, (4) Mengurangi tingkat ketergantungan daerah terhadap pusat, (5) Meningkatkan akuntabilitas, efektivitas dan efisiensi dalam rangka peningkatan kinerja daerah, (6) Meningkatkan kualitas pelayanan publik, dan (6) Memperbesar partisipasi masyarakat dalam pengambilan keputusan di sektor publik.

\section{Teori Keagenan}

Teori keagenan merupakan teori tentang suatu hubungan yang terjalin berdasarkan kontrak perjanjian antara 2 pihak atau lebih dimana pihak pertama disebut prinsipal dan pihak yang lainnya disebut dengan agen. Prinsipal merupakan pihak yang bertindak sebagai pemberi perintah dan bertugas untuk mengawasi, memberikan penilaian dan masukan atas tugas yang telah dijalankan oleh agen. Agen adalah pihak yang menerima dan menjalankan tugas sesuai dengan kehendak prinsipal.

\section{Kinerja Keuangan}

Kinerja keuangan adalah suatu ukuran kinerja yang menggunakan indikator keuangan. Analisis kinerja keuangan pada dasarnya dilakukan untuk menilai kinerja di masa lalu dengan melakukan berbagai analisis sehingga diperoleh posisi keuangan yang mewakili realitas entitas dan potensipotensi kinerja yang akan berlanjut. Menurut (Halim, 2008) analisis keuangan adalah usaha mengidentifikasi ciri-ciri keuangan berdasarkan laporan keuangan yang tersedia. Dalam organisasi pemerintah untuk mengukur kinerja keuangan ada beberapa ukuran kinerja, yaitu derajat desentralisasi, ketergantungan keuangan, rasio kemandirian keuangan daerah, rasio efektivitas, rasio efisiensi, rasio keserasian, dan pertumbuhan (Sularso dan Restianto, 2011).

\section{Rasio Derajat Desentralisasi}

Derajat Desentralisasi menunjukkan derajat kontribusi PAD terhadap total penerimaan daerah. Semakin tinggi kontribusi PAD maka semakin tinggi kemampuan daerah dalam penyelenggaraan desentralisasi (Halim, 2008 dalam Utomo, 2012).

\section{Rasio Ketergantungan Keuangan}

Dana Alokasi Umum (DAU), adalah dana yang berasal dari APBN yang dialokasikan dengan tujuan pemerataan keuangan antara daerah untuk membiayai kebutuhan pengeluarannya dalam rangka pelaksanaan desentralisasi. Berkaitan dengan perimbangan keuangan antara pusat dan daerah, hal tersebut konsekuensi adanya penyerahan kewenangan pemerintah pusat kepada pemerintah daerah. Dengan demikian terjadi transfer yang cukup signifikan di dalam APBN dari pemerintah pusat ke pemerintah daerah, pemerintah daerah secara leluasa dapat menggunakan dana ini apakah digunakan untuk memberi pelayanan yang lebih baik kepada masyarakat atau untuk keperluan lain yang tidak penting (Yustikasi, dan Darwanto, 2007 dalam Utomo, 2012). 


\section{Rasio Kemandirian Keuangan}

Rasio kemandirian keuangan daerah (otonomi fiskal) menunjukkan kemampuan daerah dalam membiayai sendiri kegiatan pemerintahan, pembangunan, dan pelayanan kepada masyarakat yang telah membayar pajak dan retribusi sebagai sumber pendapatan yang diperlukan daerah. Rasio kemandirian keuangan daerah menggambarkan ketergantungan daerah terhadap sumber dana eksternal. Semakin tinggi rasio kemandirian mengandung arti bahwa tingkat ketergantungan daerah terhadap bantuan pihak eksternal (terutama pemerintah pusat dan provinsi) semakin rendah, dan demikian pula sebaliknya. Rasio kemandirian juga menggambarkan tingkat partisipasi masyarakat dalam pembangunan daerah. Semakin tinggi rasio kemandirian, semakin tinggi partisipasi masyarakat dalam membayar pajak dan retribusi daerah yang merupakan komponen utama PAD (Halim, 2008 dalam Utomo, 2012).

\section{Rasio Efektivitas Pendapatan Asli daerah}

Rasio efektivitas menggambarkan kemampuan pemerintah daerah dalam merealisasikan PAD yang direncanakan dibandingkan dengan target yang ditetapkan berdasarkan potensi riil daerah. Kemampuan pemerintah daerah dalam menjalankan tugas dan fungsinya dikategorikan efektif apabila rasio yang dicapai minimal sebesar satu atau $100 \%$. Namun demikian, semakin tinggi rasio efektivitas maka kemampuan pemerintah daerah pun semakin baik (Halim, 2008 dalam Utomo, 2012). Pengertian efektivitas berhubungan dengan derajat keberhasilan operasi pada sektor publik sehingga suatu kegiatan dikatakan efektif jika kegiatan tersebut mempunyai pengaruh besar terhadap kemampuan menyediakan pelayanan masyarakat yang merupakan sasaran yang telah ditetapkan sebelumnya. Semakin besar realisasi penerimaan PAD dibanding target penerimaan PAD, maka dapat dikatakan semakin efektif, begitu pula sebaliknya. Nilai efektivitas diperoleh dari perbandingan sebagaimana tersebut di atas, diukur dengan kriteria penilaian kinerja keuangan (Budiarto, 2007 dalam Sularso dan Restianto, 2011).

\section{Rasio Kontribusi BUMD}

Derajat Kontribusi BUMD digunakan untuk mengetahui tingkat kontribusi perusahaan daerah/BUMD dalam mendukung pendapatan daerah. Semakin tinggi rasio ini berdampak pada naiknya pendapatan daerah (Sularso, dan Restianto, 2011).

\section{Belanja Modal}

Belanja modal adalah pengeluaran pemerintah daerah yang manfaatnya lebih dari satu tahun anggaran dan akan menambah aset atau kekayaan daerah dan berakibat menambah belanja bersifat rutin. Belanja modal diklasifikasikan dalam dua kelompok, kelompok pertama adalah belanja publik yaitu belanja yang manfaatnya dapat langsung dinikmati masyarakat. Kelompok kedua adalah belanja aparatur yaitu belanja yang manfaatnya tidak dinikmati langsung oleh masyarakat tetapi dapat dirasakan langsung oleh aparatur.

Belanja modal sangat erat kaitannya dengan investasi yang dilakukan oleh pemerintah daerah. Halim (2008), menyatakan bahwa kata investasi dapat diartikan macam-macam tergantung pada titik pandang atau konteks mengartikannya. Dalam bahasa ekonomi makro investasi dapat diartikan berbeda dengan bahasa ekonomi mikro, dan dapat berbeda pula dengan bahasa akuntansi. Dalam bahasa akuntansi pada konteks jenis belanja/biaya, investasi dapat dimunculkan dari adanya perbedaan antara revenue expenditure dan capital expenditure. Investasi termasuk dalam pengertian belanja modal adalah capital expenditure, yang didefinisikan sebagai belanja/biaya/ pengeluaran yang memberi manfaat lebih dari satu tahun. Dalam PP No. 58 tahun 2005 disebutkan bahwa belanja modal adalah pengeluaran yang dilakukan dalam rangka pembelian/pengadaan aset tetap dan aset lainnya yang mempunyai masa manfaat lebih dari 12 (dua belas) bulan untuk digunakan dalam kegiatan pemerintahan, seperti dalam bentuk tanah, peralatan, dan mesin, gedung dan bangunan, jaringan, buku perpustakaan dan hewan. 


\section{Pertumbuhan Ekonomi Daerah}

Secara umum pertumbuhan ekonomi dapat diartikan sebagai perkembangan yang menyebabkan barang dan jasa yang diproduksi dalam masyarakat bertambah dan kemakmuran masyarakat meningkat. Todaro (1997) dalam Adi (2007) secara spesifik menyebutkan ada tiga faktor atau komponen utama pertumbuhan ekonomi, yaitu akumulasi modal, pertumbuhan penduduk dan halhal yang berhubungan dengan kenaikan jumlah angkatan kerja yang dianggap secara positif merangsang pertumbuhan ekonomi.

Dalam upaya peningkatan kemandirian daerah juga dituntut untuk mengoptimalkan potensi pendapatan yang dimiliki dan salah satunya dnegan memberikan proporsi belanja modal yang besar untuk pembangunan di sektorsektor yang produktif. Salah satu faktor yang mendorong semakin tingginya kemampuan keuangan daerah adalah pertumbuhan ekonomi. Saragih (2003) mengemukakan bahwa kenaikan PAD merupakan ekses dari pertumbuhan ekonomi. Sependapat dengan hal itu, Bappenas (2004) menyatakan bahwa pertumbuhan PAD seharusnya sensitif terhadap pertumbuhan ekonomi. Kedua pendapat ini menyiratkan perlunya prioritasi kebijakan yang lebih tinggi terhadap upaya-upaya untuk meningkatkan pertumbuhan ekonomi daripada kebijakan yang lebih menekankan pada upaya peningkatan PAD secara langsung (dalam Sularso, dan Restianto, 2011).

\section{Hubungan Antara Derajat Desentralisasi Dengan Belanja Modal}

Besarnya nilai transfer yang diberikan pemerintah pusat kepada pemerintah daerah dalam bentuk dana perimbangan, seharusnya menjadi insentif untuk meningkatkan pendapatan daerah. Berdasarkan fungsinya, Pendapatan Asli Daerah (PAD) merupakan aspek penting dalam keberhasilan pelaksanaan otonomi daerah yang ditandai dengan adanya desenralisasi fiskal (Rusydi, 2010 dalam Utomo, 2012). Kenyataan yang terjadi adalah dana transfer dijadikan sumber utama penerimaan daerah dibandingkan dengan PAD. Kondisi ini ditunjukkan dengan nilai PAD yang mampu dikumpulkan daerah tidak sebanding dengan besarnya dana perimbangan yang diterima daerah. Hal ini oleh Dollrey Worthington (1999) diindikasikan sebagai ilusi fiskal dimana peningkatan PAD yang tidak seimbang dengan peningkatan dana perimbangan terhadap belanja, sehingga belanja didominasi oleh dana perimbangan (dalam Rusydi, 2010). Berdasarkan argumen tersebut maka hipotesis yang dirumuskan adalah sebagai berikut:

H1 : Desentralisasi fiskal berpengaruh positif terhadap alokasi belanja modal.

\section{Hubungan Antara Ketergantungan Keuangan Dengan Belanja Modal}

Holtz-Eakin et, al. (1985) menyatakan bahwa ada keterkaitan sangat erat antara transfer dari pemerintah pusat dengan belanja pemerintah daerah (dalam Yustikasari dan Darwanto, 2007). Sebagai konsekuensinya, adanya penyerahan kewenangan pemerintah pusat ke pemerintah daerah, terjadi transfer yang cukup signifikan di dalam APBN berkaitan dengan dana perimbangan dari pemerintah pusat ke pemerintah daerah, dan pemerintah daerah secara leluasa dapat menggunakan dana ini apakah untuk memberikan pelayanan yang lebih baik kepada masyarakat atau keperluan lain yang tidak penting (Yustikasari dan Darwanto, 2010 dalam Utomo, 2012). Tingginya tingkat ketergantungan belanja daerah terhadap pendanaan dana perimbangan, menunjukkan tingginya ketergantungan keuangan daerah terhadap pendanaan pemerintah pusat (Rusydi, 2010). Hal ini sejalan dengan Sularso dan Restianto (2011) yang menyatakan bahwa ketergantungan keuangan berpengaruh signifikan terhadap alokasi belanja modal. Berdasarkan argumen tersebut maka hipotesis yang dirumuskan adalah sebagai berikut:

H2: Ketergantungan keuangan berpengaruh positif terhadap alokasi belanja modal.

Hubungan Antara Kemandirian Keuangan Dengan Belanja Modal

Saat ini, tingkat kemandirian daerah belum dapat menunjukkan kemajuan yang berarti bahkan bila melihat kondisi 
pemerintahan saat ini kemandirian daerah cenderung menurun. Adi (2007) dalam Utomo (2012), mengindikasikan kurang seriusnya daerah dalam mengoptimalkan potensi yang dimiliki, dengan lebih mengandalkan penerimaan DAU yang bersifat hibah. Sebagai pertimbangan praktis, upaya ini lebih dipilih daripada meningkatkan PAD secara signifikan, sehingga sebagai konsekuensinya PAD yang diterima menjadi lebih kecil. Kondisi ini membuat kemandirian daerah semakin rendah. Sularso dan Restianto, (2011) menyatakan bahwa kemandirian keuangan berpengaruh terhadap alokasi belanja modal. Hal tersebut juga konsisten dengan apa yang dipaparkan oleh Harianto, dan Adi, (2007). Berdasarkan argumen tersebut maka hipotesis yang dirumuskan adalah sebagai berikut:

H3 : Kemandirian keuangan berpengaruh positif terhadap alokasi belanja modal.

\section{Hubungan Antara Efektivitas PAD Dengan Alokasi Belanja Modal}

Undang-undang No. 32 tahun 2004, salah satu sumber pendapatan daerah adalah Pendapatan Asli Daerah (PAD) yang terdiri dari hasil pajak daerah, retribusi daerah, hasil pengelolaan kekayaan daerah yang dipisahkan dan lain-lain PAD yang sah. Menurut Nugroho, (2010) peningkatan PAD diharapkan dapat meningkatkan investasi belanja modal pemerintah daerah sehingga kualitas pelayanan publik semakin baik. Yustikasari dan Darwanto, (2007) juga mengemukakan bahwa peningkatan PAD akan memberikan dampak meningkatnya pendapatan daerah yang dapat digunakan untuk meningkatkan alokasi belanja modal. Sularso dan Restianto, (2011) menyatakan bahwa efektivitas PAD berpengaruh terhadap alokasi belanja modal. Utomo, (2012) bahwa efektivitas PAD mempunyai pengaruh signifikan terhadap alokasi belanja modal. Berdasarkan argumen tersebut maka hipotesis yang dirumuskan adalah sebagai berikut:

H4: Efektivitas PAD berpengaruh positif terhadap alokasi belanja modal.

\section{Hubungan Antara Kontribusi BUMD Dengan Belanja Modal}

Derajat kontribusi BUMD digunakan untuk mengetahui tingkat kontribusi perusahaan daerah/BUMD dalam mendukung pendapatan daerah. Semakin tinggi rasio ini berdampak pada naiknya pendapatan daerah (Sularso dan Restianto, 2011). Sularso dan Restianto, (2011) juga mengemukakan bahwa derajat kontribusi BUMD berpengaruh terhadap alokasi belanja modal. Utomo (2012), menyatakan bahwa kontribusi BUMD mempunyai pengaruh yang signifkan terhadap alokasi belanja modal. Berdasarkan argumen tersebut maka hipotesis yang dirumuskan adalah sebagai berikut:

H5: Derajat Kontribusi BUMD berpengaruh positif terhadap alokasi belanja modal.

\section{Hubungan Antara Belanja Modal Dengan Pertumbuhan Ekonomi}

Todaro (1997) dalam Adi (2007) secara spesifik menyebutkan ada tiga faktor atau komponen utama pertumbuhan ekonomi, yaitu akumulasi modal, pertumbuhan penduduk dan hal-hal yang berhubungan dengan kenaikan jumlah angkatan kerja yang dianggap secara positif merangsang pertumbuhan ekonomi. Adi (2007) yang menyatakan bahwa pertumbuhan ekonomi yang selama ini terjadi sangat ditentukan oleh faktor belanja pembangunan daerah.

$$
\text { Menurut Kuncoro (2004), }
$$
pembangunan sarana dan prasarana oleh pemerintah daerah berpengaruh positif pada pertumbuhan ekonomi. Peningkatan pelayanan sektor publik secara berkelanjutan akan meningkatkan sarana dan prasarana publik, investasi pemerintah juga meliputi perbaikan fasilitas pendidikan, kesehatan, dan sarana penunjang lainnya. Berdasarkan argumen tersebut maka hipotesis yang dirumuskan adalah sebagai berikut:

H6: Alokasi belanja modal berpengaruh positif terhadap pertumbuhan ekonomi. 
Hubungan Antara Desentralisasi Fiskal Dengan Pertumbuhan Ekonomi Daerah Dengan Dimediasi Belanja Modal

Desentralisasi fiskal memungkinkan daerah untuk dapat mengelola kemampuan keuangannya sendiri dalam rangka membiayai pembangunan di daerahnya tersebut. Pembangunan berbagai fasilitas sektor publik akan berujung pada peningkatan pendapatan daerah yang berdampak pada pertumbuhan ekonomi daerah (Yustikasari dan Darwanto, 2007 dalam Utomo,2012). Brasoveanu (2007), dalam Utomo, (2012), menemukan hubungan antara kenaikan fiskal dengan pertumbuhan ekonomi. Utomo, (2012) bahwa belanja modal tidak memediasi hubungan antara desentralisasi fiskal dengan pertumbuhan ekonomi daerah. Hal ini sejalan dengan penelitian Sularso dan Restianto, (2011) menyatakan bahwa belanja modal tidak memediasi pengaruh desentralisasi fiskal terhadap pertumbuhan ekonomi. Berdasarkan argumen tersebut maka hipotesis yang dirumuskan adalah sebagai berikut:

H7: Belanja modal memediasi pengaruh desentralisasi fiskal terhadap pertumbuhan ekonomi daerah.

\section{Hubungan Antara Ketergantungan Keuangan Dengan Pertumbuhan Ekonomi Daerah Dengan Dimediasi Belanja Modal}

Tingginya tingkat ketergantungan belanja daerah terhadap pendanaan dana perimbangan, menunjukkan tingginya ketergantungan keuangan daerah terhadap pendanaan pemerintah pusat (Rusydi, 2010). Semakin tingginya rasio ketergantungan menunjukkan bahwa porsi dana transfer dalam pendapatan daerah semakin tinggi dan demikian pula sebaliknya. Semakin rendah rasio ketergantungan menunjukkan bahwa porsi dana transfer semakin rendah yang berarti kemampuan daerah semakin meningkat untuk melaksanakan pembangunan daerahnya (Sularso dan Restianto, 2011). Berdasarkan argumen tersebut maka hipotesis yang dirumuskan adalah sebagai berikut:

H8 : Belanja modal memediasi pengaruh ketergantungan keuangan terhadap pertumbuhan ekonomi daerah.

\section{Hubungan Antara Kemandirian Keuangan Dengan Pertumbuhan Ekonomi Daerah Dengan Dimediasi Belanja Modal}

Rasio kemandirian menggambarkan ketergantungan daerah terhadap sumber dana dari luar. Rasio kemandirian juga menggambarkan tingkat partisipasi masyarakat dalam pembangunan daerah. Semakin tinggi partisipasi masyarakat maka semakin tinggin rasio kemandirian, dimana tersedia dana yang cukup bagi alokasi belanja modal. Semakin tinggi rasio kemandirian maka pembangunan daerah akan semakin maju, sehingga pertumbuhan ekonomi pun dapat meningkat (Halim, 2002 dalam Sularso dan Restianto, 2011). Ani dan Dwirandra (2012), menyatakan bahwa kinerja keuangan daerah berupa rasio kemandirian berpengaruh positif dan signifikan terhadap pertumbuhan ekonomi. Berdasarkan argumen tersebut maka hipotesis yang dirumuskan adalah sebagai berikut:

H9 : Belanja modal memediasi pengaruh kemandirian terhadap pertumbuhan ekonomi.

\section{Hubungan Antara Efektivitas PAD Dengan pertumbuhan Ekonomi Daerah Dengan Dimediasi Belanja Modal}

Rasio efektivitas menggambarkan kemampuan daerah dalam merealisasikan PAD yang direncanakan dibandingkan dengan target yang ditetapkan berdasarkan potensi riil daerah. Kemampuan daerah dalam menjalankan tugasnya dikatakan efektif apabila rasio yang dicapai sebesar 1 (satu) atau 100 (seratus) persen. Namun demikian semakin tinggi rasio efektivitas menggambarkan kemampuan daerah yang semakin baik. Semakin tinggi kemampuan daerah dalam merealiasasikan PAD yang ditargetkan maka semakin dapat memenuhi kebutuhan belanja pembangunan untuk meningkatkan pertumbuhan ekonomi daerah (Sularso dan Restianto, 2011). Utomo, (2012) menyatakan bahwa belanja modal memediasi hubungan antara efektivitas PAD dengan pertumbuhan ekonomi. Hal ini sejalan dengan penelitian Sularso dan Restianto, (2012). Berdasarkan argumen tersebut maka hipotesis yang dirumuskan adalah: 
H10 : Belanja modal memediasi pengaruh efektivitas PAD terhadap pertumbuhan ekonomi daerah.

\section{Hubungan Antara Kontribusi BUMD Dengan Pertumbuhan Ekonomi Daerah Dengan Dimediasi Belanja Modal}

Pemerintah daerah dengan persetujuan DPRD dapat melakukan investasi dalam bentuk saham, modal pada Badan Usaha Milik Pemerintah dan/atau milik swasta. Derajat kontribusi BUMD digunakan untuk mengetahui tingkat kontribusi perusahaan daerah/BUMD dalam mendukung pendapatan daerah. Dengan adanya upaya dari pemerintah untuk menggali potensi-potensi daerah yang dimiliki pemerintah daerah melalui BUMD dapat meningkatkan PAD, sehingga PAD tersebut dapat digunakan untuk memenuhi kebutuhan infrastruktur baik pembangunan maupun perbaikan sarana dan prasarana. Tersedianya infrastruktur yang baik diharapkan dapat menciptakan efisiensi dan efektivitas di berbagai sektor, produktivitas masyarakat pun menjadi semakin tinggi dan pada akhirnya terjadi peningkatan pertumbuhan ekonomi di daerah tersebut (Harianto dan Adi, 2007). Semakin tinggi rasio ini berdampak pada naiknya pendapatan daerah yang berdampak pada pertumbuhan ekonomi (Sularso dan Restianto, 2011). Utomo, (2012) menyatakan bahwa belanja modal memediasi hubungan antara derajat kontribusi BUMD dengan pertumbuhan ekonomi. Berdasarkan argumen tersebut maka hipotesis yang dirumuskan adalah: H11 : Belanja modal memediasi pengaruh kontribusi BUMD terhadap pertumbuhan ekonomi.

\section{METODE PENELITIAN}

\section{Model Penelitian}

Konsekuensi logis diberlakukannya otonomi daerah adalah menyebabkan diberlakukannya desentralisasi fiskal. Dengan desentralisasi fiskal maka pemerintah daerah mempunyai wewenang lebih luas dalam pengelolaan keuangan daerah. Berdasarkan penjelasan literatur diatas maka secara skematis kerangka pemikiran penelitian dikembangkan dalam sebuah model seperti dibawah ini.

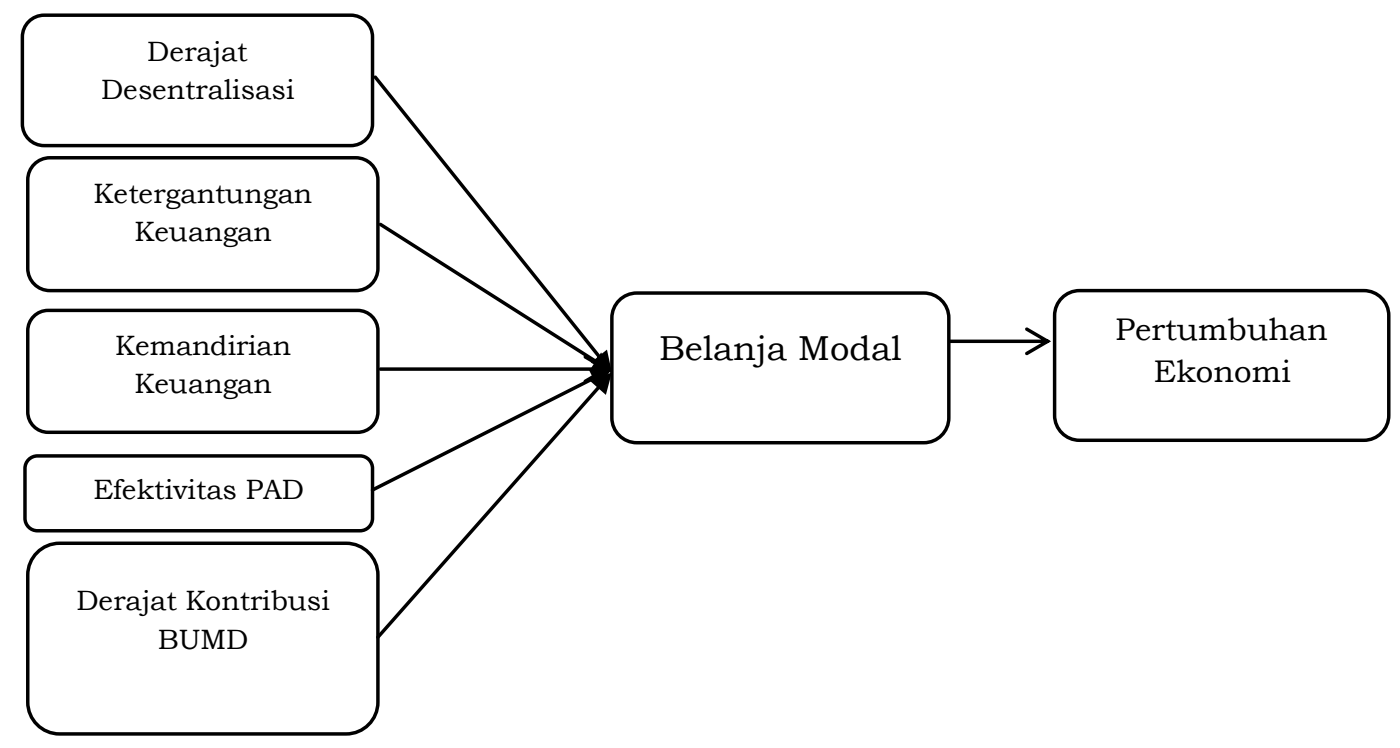

\section{Gambar 1. Model Penelitian}

\section{Obyek/Subyek Penelitian}

Populasi atau Obyek dalam penelitian ini adalah seluruh Kabupaten dan Kota yang ada di D.I.Yogjakarta, yang berjumlah 4 Kabupaten dan 1 Kota, yaitu Kota Yogjakarta, Kabupaten Bantul,
Kabupaten Sleman, Kabupaten Gunung Kidul, dan Kabupaten Kulon Progo yang mempublikasikan Laporan Keuangan Pemerintah Daerah (LKPD) secara berturut-turut dari tahun 2003 hingga tahun 2012. Metode penentuan sampel 
yang digunakan adalah metode sensus, yaitu metode yang menggunakan seluruh Kabupaten/Kota dijadikan sampel dalam penelitian ini.

\section{Jenis Data}

Jenis data yang digunakan dalam penelitian ini adalah data sekunder, yaitu data sekunder berupa Laporan Keuangan Pemerintah Daerah (LKPD) Kabupaten/Kota di D.I. Yogjakarta tahun 2003-2012, serta data non keuangan seperti data PDRB. Instrumen penelitian ini menggunakan data Anggaran Belanja dan Pendapatan Daerah (APBD) dan Laporan Realisasi Anggaran (LRA) dalam Laporan Keuangan Pemerintah Daerah (LKPD), serta data PDRB dalam laporanPertumbuhan Ekonomi tiap Kabupaten/Kota D.I. Yogyakarta.

\section{Populasi dan Sampling}

Populasi dalam penelitian ini adalah seluruh Kabupaten dan Kota yang ada di D.I. Yogjakarta, yang berjumlah 4 Kabupaten dan 1 Kota, yaitu Kota Yogjakarta, Kabupaten Bantul, Kabupaten Sleman, Kabupaten Gunung Kidul, dan Kabupaten Kulon Progoyang mempublikasikan Laporan Keuangan Pemerintah Daerah (LKPD) secara berturut-turut dari tahun 2003 hingga tahun 2012, sehingga jumlah data LKPD yang digunakan hingga tahun 2012 sebanyak 50 LKPD. Metode penentuan sampel dalam penelitian ini merupakan tehnik sensus, seluruh Kabupaten/Kota dijadikan sampel dalam penelitian ini, dan penelitian ini tidak dimaksudkan untuk menggeneralisasi suatu permasalahan tetapi menguji pengaruh antar variabel yang diteliti.

\section{Tehnik Pengumpulan Data}

Metode yang digunakan untuk mengumpulkan data dalam penelitian ini adalah metode dokumentasi, yaitu dengan cara mengumpulkan, mencatat, dan mengkaji data sekunder yang berupa Laporan Realisasi APBD yang diperoleh dari Badan Pemeriksa keuangan (BPK) serta Dinas Pengelola Keuangan dan Aset Daerah tiap Kabupaten/Kota D.I. Yogyakarta dan data PDRB dalam Pertumbuhan Ekonomi yang diperoleh dari Badan Pusat Statistik (BPS).

\section{Definisi Penelitian \\ Operasional \\ Variabel}

\section{Variabel Independen (X)}

Derajat desentralisasi menunjukkan derajat kontribusi PAD terhadap total penerimaan daerah. Semakin tinggi kontribusi PAD, maka semakin tinggi kemampuan daerah dalam penyelenggaraan desentralisasi.

Derajat desentral $=\frac{\text { Pend. Asli D 数erah }}{\text { Tot. Pend. Daerah }} \times 100 \%$

Ketergantungan keuangan dihitung dengan menggunakan jumlah pendapatan transfer dengan total penerimaan daerah. Semakin tinggi rasio ini, maka semakin besar ketergantungan daerah terhadap pemerintah pusat/provinsi.

Rasio Ktergtng $=\frac{\text { Tot Pend Transfer }}{\text { Tot Pend daerah }} \times 100 \%$

Kemandirian keuangan adalah kemampuan daerah dalam membiayai sendiri kegiatan pemerintahan, pembangunan, dan pelayanan kepada masyarakat yang telah membayar pajak dan retribusi sebagai sumber pendapatan yang diperlukan daerah.

Rasio mandiri $=\frac{\text { Pend As 拊 Daerah }}{\text { Tot Pend Transfer }} \times 100 \%$

Efektivitas PAD adalah kemampuan pemerintah daerah dalam merealisasikan PAD yang direncanakan dibandingkan dengan target yang ditetapkan berdasarkan potensi riil daerah.

Rasio Efektivitas $P A D=\frac{P A D}{\text { Total } P A D} \times 100 \%$

Derajat kontribusi BUMD digunakan untuk mengetahui tingkat kontribusi perusahaan daerah dalam mendukung pendapatan daerah.

Rasio Kontr BUMD $=\frac{\text { Penrimaan BUMD }}{\text { Total PAD }} \times 100 \%$ 


\section{Variabel Intervening}

Alokasi belanja modal adalah alokasi pengeluaran anggaran untuk perolehan aset tetap dan aset lainnya yang memberi manfaat lebih dari satu periode akuntansi, dibandingkan dengan total belanja dalam APBD.

Rasio BelanjaModal $=\frac{\text { Belanja Modal }}{\text { Total Belanja }} \times 100 \%$

\section{Variabel Dependen}

Pertumbuhan ekonomi daerah adalah kenaikan (GDP) atau PDRB tanpa memandang apakah kenaikan itu lebih besar atau lebih kecil dari tingkat pertumbuhan penduduk atau apakah terjadi perubahan struktur ekonomi.

$G=\frac{P D R B t 2-P D R B t 1}{P D R B t 1} \times 100 \%$

\section{Teknik Analisis Data}

Analisis data adalah cara yang digunakan dalam mengolah data yang diperoleh sehingga dihasilkan suatu hasil analisis (Suryabrata, 2000). Hal ini disebabkan data yang diperoleh dari penelitian tidak dapat digunakan secara langsung tetapi perlu diolah agar data tersebut dapat memberikan keterangan yang dapat dipahami, jelas, dan teliti. Penelitian menggunakan pendekatan kuantitatif dan pengujian hipotesis dilakukan dengan menggunakan model regresi linier berganda untuk menguji pengaruh masing-masing variabel independen terhadap variabel dependen secara parsial.

\section{PEMBAHASAN}

\section{Hasil uji asumsi klasik.}

Pengujian selanjutnya adalah uji asumsi klasik pada data. Uji asumsi klasik yang dilakukan dalam penelitian ini meliputi uji normalitas, uji multikolinearitas, uji heteroskedasitas, uji autokolerasi. Berikut ini adalah hasil uji asumsi klasik. Pengujian terhadap ada tidaknya pelanggaran terhadap asumsi-asumsi klasik yang merupakan dasar dalam model regresi linier berganda. Hal ini dilakukan sebelum pengujian hipotesis. Dari semua tahapan uji asumsi klasik yang dilakukan, ditemukan bahwa data berdistribusi normal dan data dinyatakan layak untuk dilakukan pengujian hipotesis.

\section{Pengujian Parsial (Uji $t$ )}

Pengujian hipotesis uji $t$ digunakan untuk melihat apakah tiap variabel bebas mempunyai pengaruh yang bermakna terhadap variabel terikat. Dari hasil pengujian parsial diperoleh sebagai berikut:

Tabel 1. Hasil Uji Hipotesis Terhadap Belanja Modal

\begin{tabular}{|c|c|c|c|c|c|}
\hline \multirow[b]{3}{*}{ Model } & \multicolumn{3}{|c|}{ Coefficients ${ }^{\mathrm{a}}$} & \multirow[b]{3}{*}{$\mathrm{T}$} & \multirow[b]{3}{*}{ Sig. } \\
\hline & \multicolumn{2}{|c|}{$\begin{array}{c}\text { Unstandardized } \\
\text { Coefficients }\end{array}$} & $\begin{array}{c}\text { Standardized } \\
\text { Coefficients }\end{array}$ & & \\
\hline & $\mathrm{B}$ & Std. Error & Beta & & \\
\hline 1 (Constant) & 51.414 & 17.293 & & 2.973 & .005 \\
\hline Desentralisasi & -.677 & .191 & -.896 & -3.546 & .001 \\
\hline Ketergantungan & -.511 & .172 & -.733 & -2.972 & .005 \\
\hline Efektivitas PAD & .133 & .065 & .293 & 2.038 & .047 \\
\hline Kontribusi BUMD & -.268 & .323 & -.137 & -.829 & .411 \\
\hline
\end{tabular}

Sumber : Data yang diolah dengan SPSS, 2014

Dari Tabel 1 dapat disimpulkan bahwa variabel derajat desentralisasi fiskal berpengaruh negatif terhadap anggaran belanja modal dengan nilai koefisien Beta sebesar -0,896, artinya setiap pertambahan $1 \%$ variabel derajat desentralisasi fiskal akan menurunkan anggaran belanja modal sebesar -0,896. Variabel ketergantungan keuangan berpengaruh negatif terhadap anggaran belanja modal dengan nilai koefisien sebesar -0,733, artinya setiap pertambahan $\quad 1 \% \quad$ variabel ketergantungan keuangan akan 
menurunkan anggaran belanja modal sebesar -0,733. Variabel efektivitas PAD berpengaruh positif terhadap anggaran belanja modal dengan nilai koefisien sebesar 0,293, artinya setiap pertambahan $1 \%$ variabel efektivitas PAD akan menaikkan anggaran belanja modal sebesar 0,293. Variabel derajat kontribusi BUMD berpengaruh negatif terhadap anggaran belanja modaldengan nilai koefisien sebesar -0,137, artinya setiap pertambahan $1 \%$ variabel derajat kontribusi BUMD akan menurunkan anggaran belanja modal sebesar -0,137.

Dari Tabel 1 dapat disimak variabel derajat desentralisasi fiskal $(-3,546>1,679)$ berpengaruh signifikan terhadap anggaran belanja modal di Kabupaten/Kota D.I. Yogyakarta dimana nilai thitung > ttabel. Nilai Sig $0,001<0,05$, namun memiliki nilai Standardized Coefficients Beta -0,896 sehingga arah pangaruhnya negatif. Dengan demikian menolak H1. Variabel ketergantungan keuangan $(-2,972>1,679)$ berpengaruh signifikan terhadap anggaran belanja modal di Kabupaten/Kota D.I. Yogyakarta dimana nilai thitung > ttabel. Nilai Sig $0,005<0,05$, namun memiliki nilai Standardized Coefficients Beta -0,733 sehingga arah pangaruhnya negatif. Dengan demikian menolak H2. Variabel efektivitas PAD $\quad(2,038>1,679)$ berpengaruh signifikan terhadap terhadap anggaran belanja modal di Kabupaten/Kota D.I. Yogyakarta dimana nilai thitung > ttabel. Nilai Sig $0,047<0,05$, akan tetapi memiliki nilai Standardized Coefficients Beta 0,293, sehingga arah pangaruhnya positif. Dengan demikian menerima H4. Variabel derajat kontribusi BUMD $(-0,829<1,679)$ tidak berpengaruh terhadap anggaran belanja modal di Kabupaten/Kota D.I.Yogyakarta dimana nilai thitung < ttabel. Nilai Sig 0,411>0,05. Dengan demikian menolak H5.

Tabel 2. Hasil Uji Hipotesis Terhadap Pertumbuhan Ekonomi

\begin{tabular}{|c|c|c|c|c|c|}
\hline \multirow[b]{3}{*}{ Model } & \multicolumn{2}{|c|}{ Coefficients $^{a}$} & \multirow[b]{2}{*}{$\begin{array}{l}\text { Standardized } \\
\text { Coefficients }\end{array}$} & \multirow[b]{3}{*}{$\mathrm{T}$} & \multirow[b]{3}{*}{ Sig. } \\
\hline & $\begin{array}{r}\text { Unsta } \\
\text { Coe }\end{array}$ & $\begin{array}{l}\text { dardized } \\
\text { icients }\end{array}$ & & & \\
\hline & $\mathrm{B}$ & Std. Error & Beta & & \\
\hline 1 (Constant) & 46.136 & 19.897 & & 2.319 & .025 \\
\hline Desentralisasi & -.351 & .227 & -.449 & -1.543 & .130 \\
\hline Ketergantungan & -.416 & 198 & -.578 & -2.105 & .041 \\
\hline Efektivitas PAD & .015 & .072 & .033 & .216 & .830 \\
\hline Kontribusi BUMD & -.009 & .342 & -.055 & -.027 & .039 \\
\hline Belanja Modal & .334 & .157 & .324 & 2.132 & \\
\hline
\end{tabular}

Sumber : Data yang diolah dengan SPSS, 2014

Dari Tabel 2 di atas dapat disimak bahwa variabel belanja modal berpengaruh positif terhadap pertumbuhan ekonomi dengan nilai koefisien Beta sebesar 0,324, artinya setiap pertambahan $1 \%$ variabel belanja modal akan menaikkan pertumbuhan ekonomi sebesar 0,324. Variabel derajat desentralisasi fiskal dimediasi oleh belanja modal berpengaruh negatif terhadap pertumbuhan ekonomi dengan nilai koefisien sebesar $-0,125$ $(-0,449 D S C R+0,324 \mathrm{BM})$, artinya setiap pertambahan $1 \%$ variabel derajat desentralisasi fiskal akan menurunkan pertumbuhan ekonomi sebesar -0,125. Variabel ketergantungan keuangan dimediasi oleh belanja modal berpengaruh negatif terhadap pertumbuhan ekonomi dengan nilai koefisien sebesar -0,254 (-0,578KGT + $0,324 \mathrm{BM})$, artinya setiap pertambahan $1 \%$ variabel ketergantungan keuangan akan menurunkan pertumbuhan ekonomi sebesar -0,254. Variabel efektivitas PAD dimediasi oleh belanja modal berpengaruh positif terhadap pertumbuhan ekonomi dengan nilai koefisien sebesar 0,357(0,033 EPAD + $0,324 \mathrm{BM})$, artinya setiap pertambahan 
$1 \%$ variabel efektivitas PAD akan menaikkan pertumbuhan ekonomi sebesar 0,357. Variabel derajat kontribusi BUMD dimediasi oleh belanja modal berpengaruh positif terhadap pertumbuhan ekonomi dengan nilai koefisien sebesar 0,319 (- 0,005KBUMD + $0,324 \mathrm{BM})$, artinya setiap pertambahan $1 \%$ variabel derajat kontribusi BUMD akan menaikkan pertumbuhan ekonomi sebesar 0,319.

Selanjutnya, variabel belanja modal $(2,132>1,680)$ berpengaruh siginifikan terhadap pertumbuhan ekonomi di Kabupaten/Kota D.I. Yogyakarta dimana nilai thitung > ttabel. Nilai Sig $0,039<0,05$, dan memiliki nilai Standardized Coefficients Beta 0,324 sehingga arah pengaruhnya positif. Dengan demikian menerima H6. Derajat desentralisasi fiskal dengan dimediasi oleh belanja modal $(-1,543<1,680)$ tidak berpengaruh terhadap pertumbuhan ekonomi di Kabupaten/Kota D.I. Yogyakarta dimana nilai thitung < ttabel. Nilai Sig 0,130>0,05, dengan demikian menolak H7. Variabel ketergantungan keuangan dengan dimediasi oleh belanja modal $(-2,105>1,680) \quad$ berpengaruh signifikan terhadap pertumbuhan ekonomi di Kabupaten/Kota D.I. Yogyakarta dimana nilai thitung $>$ ttabel. Nilai Sig 0,041<0,05, akan tetapi memiliki nilai Standardized Coefficients Beta $-0,125$, sehingga arah pengaruhnya negatif. Dengan demikian menolak H8. Variabel efektivitas PAD dengan dimediasi oleh belanja modal $(0,216<1,680) \quad$ tidak berpengaruh terhadap pertumbuhan ekonomi di Kabupaten/Kota D.I. Yogyakarta dimana nilai thitung < ttabel. Nilai Sig $0,830>0,05$, dengan demikian menolak H10. Variabel derajat kontribusi BUMD dengan dimediasi oleh belanja modal $(-0,027<1,680) \quad$ tidak berpengaruh terhadap pertumbuhan ekonomi di Kabupaten/Kota D.I. Yogyakarta dimana nilai thitung < ttabel. Nilai Sig 0,979>0,05, dengan demikian menolak H11.

Penelitian ini mengindikasikan bahwa penggalian potensi-potensi penerimaan pendapatan asli daerah (PAD) dapat dikatakan sudah baik, walaupun begitu penetapan target penerimaan pendapatan asli daerah
(PAD) terbilang masih kecil, karena penerimaan pendapatan asli daerah (PAD) belum sebanding atau masih terlalu kecil apabila dibandingkan dengan dana transfer (dana perimbangan) dari pemerintah pusatHasil temuan pada penelitian ini berhasil mendukung penelitian dari Utomo (2012), yang mengatakan bahwa derajat desentralisasi fiskal tidak mempunyai pengaruh signifkan terhadap rasio belanja modal. Hal ini sejalan dengan penelitian yang dilakukan oleh Sularso dan Restianto (2011), bahwa derajat desentralisasi tidak berpengaruh terhadap alokasi belanja modal.

Transfer yang terjadi dari pemerintah pusat ke pemerintah daerah berupa dana perimbangan memang cukup besar, namun penggunannya dalam belanja modal belum menjadi prioritas. Dengan kata lain, sebagian besar dana perimbangan digunakan untuk membiayai belanja pegawai dan belanja operasional, sehingga porsi belanja modal relatif kecil. Hasil temuan pada penelitian ini tidak berhasil mendukung penelitian dari Sularso dan Restianto (2011), menyatakan bahwa ketergantungan keuangan berpengaruh signifikan terhadap alokasi belanja modal. Hidayat (2013), menunjukkan bahwa tingkat kemandirian tahun lalu berpengaruh signifikan terhadap alokasi belanja modal. Namun hal ini sejalan dengan penelitian Utomo (2012), bahwa bahwa ketergantungan keuangan tidak mempunyai pengaruh signifikan terhadap alokasi belanja modal.

Rasio efektifiitas PAD mempunyai pengaruh signifikan terhadap rasio alokasi belanja modal dengan arah pengaruh positif, hal ini dimungkinkan karena penetapan target PAD yang ditetapkan masih tergolong rendah sehingga dapat dicapai, atau bisa jadi penggalian potensi PAD ini dapat dikatakan maksimal sebagai sumber pendapatan dalam membangun daerah. Pemerintah Daerah Kabupaten/Kota D.I. Yogyakarta dari tahun 2003-2012 mengalami peningkatan pendapatan asli daerah (PAD) yang cukup signifikan. Pemerintah daerah berupaya mengoptimalkan potensi pendapatan asli daerah sebagai bagian utama dalam penyusunan APBD dalam pengalokasian 
belanja daerah sebagai upaya meminimalkan ketergantungan penerimaan dari pemerintah pusat. Walaupun kenyataanya penggunaan dana pendapatan asli daerah sudah dioptimalkan guna membiayai pengeluaran/belanja daerah khususnya belanja modal, tetapi belum sepenuhnya kebutuhan belanja daerah terpenuhi.

Di sisi lain belanja modal juga di pengaruhi oleh dana perimbangan, walaupun penggunaan dana perimbangan untuk pengalokasian belanja modal masih relatif kecil, dikarenakan penggunaan dana perimbangan digunakan untuk belanja yang lainnya, seperti belanja pegawai dan belanja operasional. Oleh karena itu Pemerintah Daerah Kabupaten/Kota D.I. Yogyakarta berupaya maksimal dalam menggali potensi-potensi penerimaan daerah dalam rangka meningkatkan alokasi belanja modal guna pembangunan daerah. Sebenarnya untuk perealisasian PAD untuk Kabupaten/ Kota D.I. Yogyakarta sudah efektif, karena pencapaian sudah sebesar 1 (satu) atau $100 \%$. Hasil temuan pada penelitian ini berhasil mendukung penelitian dari Sularso dan Restianto, (2011) menyatakan bahwa efektivitas PAD berpengaruh terhadap alokasi belanja modal. Sejalan dengan hal ini penelitian Utomo (2012), bahwa efektivitas PAD mempunyai pengaruh signifikan terhadap alokasi belanja modal.

BUMD secara ideal merupakan salah satu sumber penerimaan dari sebuah pemerintahan daerah. BUMD adalah sebuah perwujudan dari peran pemerintah daerah dalam pembangunan ekonomi daerah. Namun demikian dalam perkembangannya BUMD justru menjadi salah satu titik lemah keuangan daerah. Alih-alih menjadi sumber penerimaan, BUMD justru membebani keuangan daerah. Penelitian yang dilakukan, memberikan temuan-temuan menarik terkait dengan kinerja BUMD. BUMD di beberapa Kabupaten/Kota ternyata tidak efisien dalam operasionalnya. BUMD pada umumnya menghadapi berbagai kendala klasik dalam pengoperasiannya seperti masalah modal, sistem manajemen, dan sumber daya manusia. Oleh karena itu menjadikan masih rendahnya penerimaan laba dan kurangnya manajamen yang baik sehingga menyebabkan rendahnya penerimaan Pendapatan Asli Daerah (PAD) Kabupaten/Kota D.I. Yogyakarta. Hasil temuan pada penelitian ini tidak berhasil mendukung penelitian dari Sularso dan Restianto (2011), yang mengemukakan bahwa derajat kontribusi BUMD berpengaruh terhadap alokasi belanja modal. Utomo (2012), juga menyatakan bahwa kontribusi BUMD mempunyai pengaruh yang signifkan terhadap alokasi belanja modal.

Selanjutnya, alokasi belanja modal ditemukan tidak berpengaruh terhadap pertumbuhan ekonomi daerah. Hal ini dimungkinkan karena dalam periode penelitian ini porsi belanja modal digunakan sebagaimana mestinya untuk membangun sarana dan prasarana kebutuhan masyarakat secara tepat sasaran. Belanja modal dipergunakan untuk membiayai penambahan infrastruktur yang ada atau sarana dan prasarana yang memadai. Kuncoro (2004), pembangunan sarana dan prasarana oleh pemerintah daerah berpengaruh positif pada pertumbuhan ekonomi. Peningkatan pelayanan sektor publik secara berkelanjutan akan meningkatkan sarana dan prasarana publik, investasi pemerintah juga meliputi perbaikan fasilitas pendidikan, kesehatan, dan sarana penunjang lainnya. Syarat fundamental untuk pembangunan ekonomi adalah tingkat pengadaan modal pembangunan yang seimbang dengan pertambahan penduduk. Pembentukan modal tersebut harus didefinisikan secara luas sehingga mencakup semua pengeluaran yang sifatnya menaikkan produktivitas (Ismerdekaningsih dan Rahayu, 2002). Dengan ditambahnya infrastruktur dan perbaikan infrastruktur yang ada oleh pemerintah daerah, diharapkan akan memacu pertumbuhan perekonomian di daerah (Adi dan Harianto, 2007). Hasil temuan pada penelitian ini berhasil mendukung penelitian dari Sularso dan Restianto (2011), yang menyatakan bahwa belanja modal berpengaruh terhadap pertumbuhan ekonomi. Sejalan dengan hal ini, Utomo (2012), juga mengemukakan bahwa belanja modal 
berpengaruh terhadap pertumbuhan ekonomi.

Belanja modal juga tidak memiliki pengaruh signifikan terhadap rasio pertumbuhan ekonomi. Hal itu dikarenakan belanja modal dari tahun 2003-2012 untuk kabupaten/kota D.I.Yogyakarta mengalami kenaikan dan penurunan yang signifikan. Seharusnya dengan meningkatnya desentralisasi, meningkatnya dana perimbangan dari tahun ke tahun mampu meningkatkan alokasi anggaran belanja modal guna membiayai pembangunan di daerahnya tersebut. Sehingga pertumbuhan ekonominya pun akan meningkat. Akan tetapi seperti yang sudah dijelaskan di awal, bahwa alokasi belanja modal lebih dititikberatkan kepada penggunaan PAD yang di dapat, hal itu disebabkan dana perimbangan yang selama ini porsinya lebih di anggarkan ke belanja pegawai. Desentralisasi akan berdampak terhadap pertumbuhan ekonomi apabila desentralisasi fiskal dipusatkan pada pengeluaran atau pembelanjaan publik, seperti belanja modal guna pembangunan di daerah tersebut. Hasil temuan pada penelitian ini berhasil mendukung penelitian dari Utomo, (2012) bahwa belanja modal tidak memediasi hubungan antara desentralisasi fiskal dengan pertumbuhan ekonomi daerah. Hal ini sejalan dengan penelitian Sularso dan Restianto, (2011) menyatakan bahwa belanja modal tidak memediasi pengaruh desentralisasi fiskal terhadap pertumbuhan ekonomi.

Rasio ketergantungan keuangan mempunyai pengaruh signifikan terhadap pertumbuhan ekonomi daerah dengan dimediasi belanja modal, dan memiliki arah pengaruh negatif, hal ini dimungkinkan karena penggunaan dana perimbangan dalam alokasi belanja modal masih relatif kecil, sebagian besar dana perimbangan masih digunakan untuk belanja pegawai dan belanja operasional. Tingginya tingkat ketergantungan belanja daerah terhadap pendanaan dana perimbangan, menunjukkan tingginya ketergantungan keuangan daerah terhadap pendanaan pemerintah pusat (Rusydi, 2010). Semakin tingginya rasio ketergantungan menunjukkan bahwa porsi dana transfer dalam pendapatan daerah semakin tinggi dan demikian pula sebaliknya. Semakin rendah rasio ketergantungan menunjukkan bahwa porsi dana transfer semakin rendah yang berarti kemampuan daerah semakin meningkat untuk melaksanakan pembangunan daerahnya (Sularso dan Restianto, 2011). Namun hasil temuan pada penelitian ini, tidak sejalan dengan penelitian dari Sularso dan Restianto, (2011) yang menyatakan bahwa belanja modal memediasi pengaruh ketergantungan keuangan terhadap pertumbuhan ekonomi. Akan tetapi penelitian ini sejalan dengan penelitian Utomo (2012), bahwa belanja modal tidak memediasi pengaruh ketergantungan keuangan terhadap pertumbuhan ekonomi daerah. Berdasarkan penelitian yang dilakukan Kusumadewi, dan Arif Rahman, (2007) juga menemukan bahwa dana transfer DAU pemerintah pusat tidak mempunyai pengaruh terhadap belanja modal sebagai stimulus pertumbuhan ekonomi.

Belanja modal juga tidak memiliki pengaruh terhadap rasio pertumbuhan ekonomi.Hal ini mengindikasikan bahwa daerah yang memiliki tingkat efektifitas PAD yang tinggi tidak selalu tingkat pertumbuhan ekonomi daerah tersebut tinggi juga dikarenakan tidak diimbangi dengan alokasi belanja modal yang tinggi juga. Rasio efektivitas menggambarkan kemampuan daerah dalam merealisasikan PAD yang direncanakan dibandingkan dengan target yang ditetapkan berdasarkan potensi riil daerah. Kemampuan daerah dalam menjalankan tugasnya dikatakan efektif apabila rasio yang dicapai sebesar 1 (satu) atau 100\%. Namun demikian semakin tinggi rasio efektivitas menggambarkan kemampuan daerah yang semakin baik. Semakin tinggi kemampuan daerah dalam merealiasasikan PAD yang ditargetkan maka semakin dapat memenuhi kebutuhan belanja pembangunan untuk meningkatkan pertumbuhan ekonomi daerah (Sularso dan Restianto, 2011). Hasil temuan pada penelitian ini sejalan dengan penelitian yang dilakukan oleh Kawa, (2011) menyatakan bahwa rasio efektivitas PAD tidak berpengaruh signifikan terhadap pertumbuhan ekonomi. Dan didukung oleh penelitian 
yang dilakukan oleh Hamzah (2008), yang juga menyatakan bahwa rasio efektivitas PAD tidak berpengaruh terhadap pertumbuhan ekonomi. Namun, hasil penelitian ini tidak berhasil mendukung penelitian dari Utomo, (2012) menyatakan bahwa belanja modal memediasi hubungan antara efektivitas PAD dengan pertumbuhan ekonomi. Sularso dan Restianto, (2012) bahwa belanja modal memediasi hubungan antara efektivitas PAD dengan pertumbuhan ekonomi.

Kontribusi BUMD dengan dimediasi oleh belanja modal dalam penelitian ini tidak memiliki pengaruh terhadap rasio pertumbuhan ekonomi. Dengan adanya upaya dari pemerintah untuk menggali potensi-potensi daerah yang dimiliki pemerintah daerah melalui BUMD dapat meningkatkan PAD, sehingga PAD tersebut dapat digunakan untuk memenuhi kebutuhan infrastruktur baik pembangunan maupun perbaikan sarana dan prasarana. Namun penyerapan atau penggalian potensi-potensi pendapatan asli daerah melalui Badan Usaha Milik Daerah (BUMD) sudah optimal tetapi hasilnya belum maksimal dikarenaka masih terbatasnya perusahaanperusahaan daerah yang ada di Kabupaten/Kota D.I. Yogyakarta. Tersedianya infrastruktur yang baik diharapkan dapat menciptakan efisiensi dan efektivitas di berbagai sektor, produktivitas masyarakat pun menjadi semakin tinggi dan pada akhirnya terjadi peningkatan pertumbuhan ekonomi di daerah tersebut (Harianto dan Adi, 2007). Semakin tinggi rasio ini berdampak pada naiknya pendapatan daerah yang berdampak pada pertumbuhan ekonomi (Sularso dan Restianto, 2011).Namun penggalian potensi-potensi penerimaan asli daerah melalui perusahaan daerah (BUMD) tampaknya masih belum optimal dan tepat sasaran dikarenakan penggunaan PAD untuk memenuhi kebutuhan infrastruktur baik pembangunan maupun perbaikan sarana dan prasarana masih belum maksimal, dikarenakan porsi belanja modal yang digunakan untuk memenuhi kebutuhan infrastruktur tidaklah cukup apabila hanya mengandalkan PAD yang diperoleh dari perusahaan daerah, tetapi lebih mengandalkan penerimaan dana perimbangan. Hasil penelitian ini tidak berhasil mendukung penelitian dari Prasetyo Utomo, (2012) menyatakan bahwa belanja modal memediasi hubungan antara derajat kontribusi BUMD dengan pertumbuhan ekonomi. Hal ini sejalan dengan penelitian, Sularso dan Restianto, (2011) menyatakan bahwa belanja modal memediasi hubungan antara derajat kontribusi BUMD dengan pertumbuhan ekonomi.

\section{PENUTUP}

\section{Simpulan}

Berdasarkan analisis data dan pembahasan yang telah dilakukan maka dapat diambil kesimpulan bahwa hipotesis pertama tidak didukung atau dapat dikatakan bahwa derajat desentralisasi fiskal berpengaruh negatif dan signifikan terhadap anggaran belanja modal. Derajat desentralisasi menunjukkan derajat kontribusi PAD terhadap total penerimaan daerah. Semakin tinggi kontribusi PAD, maka semakin tinggi kemampuan daerah dalam penyelenggaraan desentralisasi. Hasil penelitian ini sejalan dengan penelitian dari Prasetyo Utomo (2012), mengatakan bahwa derajat desentralisasi fiskal tidak mempunyai pengaruh signifkan terhadap rasio belanja modal.

Hipotesis kedua tidak didukung atau dapat dikatakan bahwa ketergantungan keuangan berpengaruh negatif dan signifikan terhadap anggaran belanja modal. Ketergantungan keuangan dihitung dengan menggunakan jumlah pendapatan transfer dengan total penerimaan daerah. Semakin tinggi rasio ini, maka semakin besar ketergantungan daerah terhadap pemerintah pusat/ provinsi. Hasil penelitian ini sejalan dengan penelitian dari Sularso dan Restianto (2011), menyatakan bahwa ketergantungan keuangan berpengaruh signifikan terhadap alokasi belanja modal.

Hipotesis keempat didukung atau dapat dikatakan bahwa efektivitas PAD berpengaruh positif dan signifikan terhadap anggaran belanja modal. Efektivitas PAD adalah kemampuan pemerintah daerah dalam merealisasikan PAD yang direncanakan dibandingkan 
dengan target yang ditetapkan berdasarkan potensi riil daerah. Hasil penelitian ini sejalan dengan penelitian dari Prasetyo Utomo, (2012) bahwa efektivitas PAD mempunyai pengaruh signifikan terhadap alokasi belanja modal.

Hipotesis kelima tidak didukung atau dapat dikatakan bahwa derajat kontribusi BUMD tidak berpengaruh signifikan terhadap anggaran belanja modal. Derajat kontribusi BUMD digunakan untuk mengetahui tingkat kontribusi perusahaan daerah dalam mendukung pendapatan daerah. Hasil penelitian ini tidak sejalan dengan penelitian dari Sularso dan Restianto, (2011) yang mengemukakan bahwa derajat kontribusi BUMD berpengaruh terhadap alokasi belanja modal.

Hipotesis keenam didukung atau dapat dikatakan bahwa belanja modal berpengaruh positif dan signifikan terhadap pertumbuhan ekonomi daerah. Alokasi belanja modal adalah alokasi pengeluaran anggaran untuk perolehan aset tetap dan aset lainnya yang memberi manfaat lebih dari satu periode akuntansi, dibandingkan dengan total belanja dalam APBD. Hasil penelitian ini sejalan dengan penelitian dari Prasetyo Utomo (2012), juga mengemukakan bahwa belanja modal berpengaruh terhadap pertumbuhan ekonomi.

Hipotesis ketujuh tidak didukung atau dapat dikatakan bahwa derajat desentralisasi dengan dimediasi oleh belanja modal tidak berpengaruh signifikan terhadap pertumbuhan ekonomi daerah. Hasil penelitian ini sejalan dengan penelitian dari Sularso dan Restianto, (2011) menyatakan bahwa belanja modal tidak memediasi pengaruh desentralisasi fiskal terhadap pertumbuhan ekonomi.

Hipotesis kedelapan tidak didukung atau dapat dikatakan bahwa ketergantungan keuangan dengan dimediasi oleh belanja modal berpengaruh negatif dan signifikan terhadap pertumbuhan ekonomi daerah. Hasil penelitian ini sejalan dengan penelitian Utomo (2012), bahwa belanja modal tidak memediasi pengaruh ketergantungan keuangan terhadap pertumbuhan ekonomi daerah.
Hipotesis kesepuluh tidak didukung atau dapat dikatakan bahwa efektivitas PAD dengan dimediasi oleh belanja modal tidak berpengaruh signifikan terhadap pertumbuhan ekonomi daerah. Hasil penelitian ini sejalan dengan penelitian Erlangga Pati Kawa, (2011) menyatakan bahwa rasio efektivitas PAD tidak berpengaruh signifikan terhadap pertumbuhan ekonomi. Namum tidak sejalan dengan penelitian dari Prasetyo Utomo, (2012) menyatakan bahwa belanja modal memediasi hubungan antara efektivitas PAD dengan pertumbuhan ekonomi.

Hipotesis kesebelas tidak didukung atau dapat dikatakan bahwa kontribusi BUMD dengan dimediasi oleh belanja modal tidak berpengaruh signifikan terhadap pertumbuhan ekonomi daerah. Hasil penelitian ini tidak sejalan dengan penelitian Sularso dan Restianto, (2011) menyatakan bahwa belanja modal memediasi hubungan antara derajat kontribusi BUMD dengan pertumbuhan ekonomi.

\section{Keterbatasan}

Penelitian ini tidak terlepas dari keterbatasan dan kekurangan. Keterbatasan dalam penelitian ini adalah dihilangkannya variabel kemandirian keuangan, dikarenakan variabel tersebut memiliki korelasi nilai VIF paling besar sehingga menyebabkan gejala multikolinearitas pada regresi persamaan 1 dan persamaan 2. Beberapa tahap yang telah dilakukan untuk menghilangkan gejala multikolinearitas pada variabel independen pada persamaan 1 dan persamaan 2, yaitu mentransformasikan data ke dalam bentuk lain, misalnya logaritma natural, akar kuadrat atau bentuk first difference delta. Kemudian menambah jumlah observasi dan mengganti atau mengeluarkan variabel yang mempunyai korelasi yang tinggi.

\section{Saran}

Berdasarkan keterbatasan dan hasil penelitian yang telah dilakukan, maka peneliti memberikan beberapa saran untuk penelitian selanjutnya, yaitu memperbanyak populasi penelitian sehingga jumlah sampel juga lebih mampu untuk dapat dilakukan 
generalisasi atas hasil tersebut, menambahkan indikator untuk mengukur variabel kinerja keuangan daerah, dan menguji pengaruh langsung antara kinerja keuangan daerah dengan pertumbuhan ekonomi daerah.

\section{DAFTAR PUSTAKA}

Abdullah, Syukriy and Halim Abdul, 2004. "Pengaruh Dana Alokasi Umum (DAU) dan Pendapatan Asli Daerah (PAD) terhadap Belanja Pemerintah Daerah: Studi Kasus Kabupaten/Kota di Jawa dan Bali." Proceeding Simposium Nasional Akuntansi VI, 16-17 Oktober 2003, Surabaya, hal. 1140.

Abimanyu, Anggito. 2005. Format Anggaran Terpadu Menghilangkan Tumpang Tindih. Bapekki Depkeu.

Adi, P.H. 2005. "Dampak Desentralisasi Fiskal terhadap Pertumbuhan Ekonomi (Studi pada Kabupaten dan Kota se Jawa-Bali)". Jurnal Kritis Universitas Kristen Satya Wacana Salatiga.

Adi, P. H. 2007. "Hubungan antara Pertumbuhan Ekonomi Daerah, Belanja Pembangunan dan Pendapatan Asli Daerah (Studi pada Kabupaten dan Kota se JawaBali)". Jurnal Akuntansi dan Keuangan Sektor Publik, Vol 08, No. 1.

Andrea Christy, Fhino and Priyo Hari Adi. 2009. "Hubungan Antara Dana Alokasi Umum, Belanja Modal dan Kualitas Pembangunan Manusia." Makalah disampaikan dalam Konferensi Nasional UKWMS. Surabaya 10 0ktober 2009.

Ani and Dwirandra (2012). Pengaruh Kinerja Keuangan Pada Pertumbuhan Ekonomi, Pengangguran, dan Kemiskinan Kabupaten dan Kota.

Ardhini and Handayani (2011). Pengaruh Rasio Keuangan Daerah terhadap Belanja Modal untuk Pelayanan Publik dalam Perspektif Teori Keagenan (Studi Pada Kabupaten dan Kota Di Jawa Tengah)

Bappenas. 2004. Indonesia. Laporan Perkembangan Pencapaian Tujuan Pembangunan Millenium (Millenium
Development Goals). Jakarta: Bappenas.

Endah Kusumawati, Vegasari. 2011. Faktor-Faktor Yang Menentukkan Pendapatan Asli Daerah dan Belanja Modal di Indonesia Survey pada Pemerintah di Indonesia Bagian Barat dan tengah.

Fitriyanti \& Pratolo. (2008). "Pengaruh Pendapatan Asli Daerah dan Belanja Pembangunan Terhadap Rasio Kemandirian dan Pertumbuhan Ekonomi." Proceeding Konferensi Penelitian Keuangan Sektor Publik, Jakarta.

Ghozali, Imam, 2006. Aplikasi Analisis Multivarite dengan SPSS, Cetakan Keempat, Badan Penerbit Universitas Dipenogoro, Semarang.

Halim, A. (2007). Akuntansi Sektor Publik; Akuntansi Keuangan Daerah, Salemba Empat, Jakarta

Halim, A. and Abdullah, S. 2006. "Hubungan dan Masalah Keagenan di Pemerintahan Daerah (Sebuah Peluang Penelitian Anggaran dan Akuntansi)." Jurnal Akuntansi Pemerintah Vol.2 No.1, hal 53-64.

Hamzah, A. (2008). Analisa Kinerja Keuangan terhadap Pertumbuhan Ekonomi, Pengangguran dan Kemiskinan: Pendekatan Analisis Jalur, Universitas Trunojoyo.

Handra, Hefrizal and Maryati, Sri. 2009. "Analisis Pendapatan Asli Daerah (PAD) Bukan Pajak Pemerintah Propinsi Sumatra Barat." Konferensi Penelitian Keuangan Sektor Publik II Badan Litbang Departemen Dalam Negeri.

Harianto, David and Priyo Hari Adi, 2007. "Hubungan Antara Dana Alokasi Umum, Belanja Modal, Pendapatan Asli Daerah, dan Pendapatan PerKapita." Simposium Nasional Akuntansi X, Makassar.

Hidayat, Mochamad Fajar. 2013. Analisis Pengaruh Kinerja Keuangan Daerah terhadap Alokasi Belanja Modal. Universitas Brawijaya, Malang.

Hendarmin. 2013. Pengaruh Belanja Modal Pemerintah Daerah dan Investasi Swasta terhadap Pertumbuhan Ekonomi, Kesempatan Kerja dan Kesejahteraan 
Masyarakat di Kabupaten/Kota Propinsi Kalimantan Barat. UNTAN.

Ismerdekaningsih, Herlina, SE \& Endah Sri Rahayu, SE. 2002, "Analisis Hubungan Penerimaan Pajak Terhadap Product Domestic Bruto Di Indonesia (Studi Tahun 19852000)." ITB Central Library

Kawa, Erlangga Pati. 2011. Pengaruh Kinerja Keuangan Pemerintah Daerah terhadap Pertumbuhan Ekonomi Daerah Pasca Pelaksanaan Undang-Undang Otonomi Daerah (Studi pada Pemerintah Kabupaten/Kota di Indonesia). Universitas Sebelas Maret, Surakarta.

Khusaini, Mohammad. 2006. Ekonomi Publik: Desentralisasi Fiskal dan Pembangunan Daerah. Malang: BPFE Unibraw.

Kuncoro,Haryo. (2004). Pengaruh Transfer antar Pemerintah Pada Kinerja Fiscal Pemerintah Daerah Kota dan Kabupaten Di Indonesia. Vol. 9 no. 1

Kusumadewi and Arif Rahman (2007). Flypaper Effect pada Dana Alokasi Umum (DAU), dan Pendapatan Asli Daerah (PAD) terhadap Belanja Daerah pada Kabupaten/Kota di Indonesia

Nugroho, Fajar dan Rohman, Abdul. (2012). Pengaruh Belanja Modal Terhadap Pertumbuhan Kinerja Keuangan Daerah Dengan Pendapatan Asli Daerah Sebagai Variabel Intervening (Studi Kasus Di Provinsi Jawa Tengah). Universitas Dipenogoro, Semarang.

Peraturan Menteri Dalam Negeri Nomor 13 Tahun 2006 tentang Pedoman Pengelolaan Keuangan Daerah.

Peraturan Pemerintah Nomor 24 Tahun 2005 tentang Standar Akuntansi Pemerintahan.

Peraturan Pemerintah Nomor 58 Tahun 2005 tentang Pengelolaan Keuangan Daerah.

PSAP Nomor 2 Laporan Realisasi Anggaran

Rahmawati, Nur Indah. 2010. Pengaruh Pendapatan Asli Daerah (PAD) Dan Dana Alokasi Umum (DAU) Terhadap Alokasi Belanja Daerah. UNDIP. Semarang.
Rusydi, Bahrul Ulum. 2010. Analisis Determinan Kinerja Keuangan Pemerintah Daerah Dan Deteksi Ilusi Fiskal. Universitas Dipenogoro, Semarang.

Saragih, Juli Panglima. 2003. Desentralisasi Fiskal dan Keuangan Daerah dalam Otonomi. Cetakan Pertama. Penerbit Ghalia Indonesia: Jakarta.

Sekaran, Uma., 2006, Research Methods For Bussiness Metodologi Penelitian untuk bisnis buku 1, Jakarta: Salemba Empat.

Sumadi Suryabrata, 2000. Metode Penelitian. PT. Raja Grafindo Persada, Jakarta.

Sularso dan Restianto. 2011. Pengaruh Kinerja Keuangan Terhadap Alokasi Belanja Modal dan Pertumbuhan Ekonomi Kabupaten/Kota Di jawa Tengah. Universitas Jendral Soedirman, Purwokerto.

Susanto, Azhar. 2008. Sistem Informasi Akuntansi, Struktur-Pengendalian Resiko-Pengembangan. Bandung: Lingga Jaya.

Republik Indonesia, Undang-Undang Nomor 22 Tahun 1999 tentang Pemerintah Daerah

Republik Indonesia, Undang-Undang Nomor 25 tahun 1999 tentang Perimbangan Keuangan Antara Pemerintah Pusat Dan Daerah

Republik Indonesia, Undang-Undang Nomor 32 Tahun 2004 Pasal 7 tentang Pemerintah Daerah

Utomo, Susilo Prasetyo. 2012. Pengaruh Kinerja Keuangan Terhadap Pertumbuhan Ekonomi Daerah Dengan Alokasi Belanja Modal Sebagai Variabel Pemediasi. Universitas Sebelah Maret, Surakarta.

Yustikasari dan Darwanto (2007). Pengaruh Pertumbuhan Ekonomi, Pendapatan Asli Daerah, Dan Dana Alokasi Umum Terhadap Pengalokasian Anggaran Belanja Modal. 